\title{
CURA INTERIOR À LUZ DA BÍBLIA
}

Edson José Lira Turiano ${ }^{1}$

\section{RESUMO}

Cura interior é um processo em que a ação do Espírito Santo sara as feridas da alma. Essas feridas têm sua origem em algum fato ruim do passado e a cura oferece a oportunidade de o cristão restaurar-se e viver todo seu potencial. Esse processo tem contribuído para libertação de muitas pessoas e começa quando se toma uma atitude, S1 32: 3, de reação contra os problemas interiores que aprisionam a mente e o comportamento. Deus realiza uma obra completa, mas há crentes que ainda não descobriram isso.Todo ser humano tem uma história de vida e o que já fizerem contra você produziu feridas interiores que precisam ser saradas. Somos a melhor pessoa para ajudar a nós mesmos. Se procurarmos ajuda em Deus, encontraremos, mas é preciso extrair forças de onde, aparentemente, não existem mais. É o momento de ser tão forte como nunca foi, pois quem lhe fortalece é o Senhor: "faz forte ao cansado e multiplica as forças ao que não tem nenhum vigor", Is 40: 29. É sobre isso que conversaremos a partir de agora.

Palavras-chave: Cura interior; Alma; Deus.

\section{INTRODUÇÃO}

Há muitos cristãos que já ajudaram a muitos, auxiliaram a outros, mas não conseguem superar os próprios problemas. Agora chegou a sua vez. Se percebe que em seu mundo interior há desajustes entre o espírito e a alma, você precisa ser tratado. O crente em Jesus Cristo pode ser feliz e declarar: "tudo posso naquele que me fortalece", Fp 4: 13. Mas, para isso, seu interior precisa ser curado.

Examinemo-nos a nós mesmos, identifiquemos nossos problemas, coloquemo-os na presença de Deus e permitamos a ação do Espírito Santo em nossa alma. Com as feridas saradas, aprendemos a manter bom equilíbrio e façamos todo esforço possível para vencer. Não nos deixemos dominar, mas dominenos, lutemos por nossa auto-estima. Lembromo-nos de que nosso passado não é nosso presente. Por isso, em Cristo, libertemo-nos dos traumas, das

\footnotetext{
${ }^{1}$ Doutor em Ciências da Religião - FICS - Facultad Interamericana de Ciencias Sociales

E-mail: eturianolira@yahoo.com.br
} 
lembranças do passado, das amarguras, dos ressentimentos e sejamos mais que vencedor. Para isso, liberemos perdão.

Cura interior é a cura do nosso homem interior:- da mente, emoções, lembranças desagradáveis, sonhos. É o processo pelo qual, por meio da oração a Deus Pai, em nome do Seu filho Jesus Cristo, somos libertos de sentimentos de ressentimento, rejeição, auto piedade, depressão, culpa, medo, tristeza, ódio, complexo de inferioridade, autocondenação, etc.

Em Romanos 12.2, lemos o seguinte: "E não vos conformeis com este século, mas transformai-vos pela renovação da vossa mente..." A cura interior é a renovação de nossa mente.

Cura interior é a cura das feridas emocionais, e é o processo da conscientização da nossa situação. Certas áreas da nossa vida precisam de um toque especial do Espírito Santo de Deus.

O ser humano é composto por três elementos:- corpo, alma, espírito. O corpo é o elemento pelo qual contatamos o mundo físico, ele é matéria, e precisamos dele no mundo material, recebemos um corpo para podermos viver nesta terra; Já a alma e o elemento com o qual contatamos a humanidade. É a sede da inteligência, dos sentimentos, da vontade, e das emoções do homem, e nela ficam localizadas as lembranças boas e más; O espírito é o elemento com o qual nos comunicamos com a divindade, é o único que pode nos levar a Deus. "O vento sopra onde quer, e ouves a sua voz; mas não sabes donde vem, nem para onde vai; assim é todo aquele que é nascido do Espírito." - João 3:3-8

A Palavra de Deus é uma fonte extraordinária, porque trabalha no íntimo do ser humano, trazendo a cura para a alma. Hebreus 4:12 diz: " Porque a palavra de Deus é viva e eficaz, e mais cortante do que qualquer espada de dois gumes, e penetra até a divisão de alma e espírito, e de juntas e medulas, e é apta para discernir os pensamentos e intenções do coração."

A nossa alma se compõe de: sentimento, vontade, consciência, pensamento, nestas áreas somos feridos, somos agredidos por outros seres humanos, ficando assim com a mente ferida, doente.

As próprias famílias são uma das fontes que podem levar a pessoa a ter uma enfermidade na alma. A família é a espinha dorsal da estrutura da personalidade do indivíduo, é o seu primeiro relacionamento e portanto a sua referência. Antes mesmo de nascer, a criança já recebe como herança a influência de seus pais, e, com o tempo, outras influências se acumularão com a herança sociológica, a psicológica e a espiritual.

Isto significa que uma família pode transmitir boas influências a uma pessoa tornando a sua personalidade estruturada. Como pode também acontecer o contrário, transferir más influências e a pessoa adquirir personalidade desestruturada. Inegavelmente tanto no aspecto genético como no espiritual, nós somos o reflexo dos nossos parentes, com os quais 
convivemos. Quando temos um lar desestruturado, com certeza enfrentaremos alguns problemas quando adultos.

O ser humano é dotado de inteligência, de vontade própria, de sentimento e de livrearbítrio, o que o torna responsável por suas próprias escolhas. A pessoa, por tomar decisões erradas na vida, por assumir procedimentos errados, pode atrair para si muitas doenças na área emocional, porque o remorso, o arrependimento e a culpa doem, e as consequências são inevitáveis.

"Por que se queixaria o homem vivente, o varão por causa do castigo dos seus pecados?" - Lamentações 3:39

O homem muitas vezes convive com o sentimento de insatisfação consigo mesmo. É o caso de pessoas que tentaram agradar seus pais com toda dedicação, mas nunca conseguiram. Sempre ficavam aquém do resultado esperado; Tiravam sete na prova, porém tinha que ser um 10, arrumavam a cama do jeito que uma criança é capaz de arrumar mas, sempre lhe era exigido mais e nunca estava bom para o adulto. Isso o levava a sentimentos de incompetência lutava incansavelmente para ser o melhor, mas nunca conseguia, por isso acabaram frustrados, desanimados e o fazia carregar um fardo enorme, isso causou uma ferida que precisa ser curada.

Algumas pessoas sofreram muitas mágoas, desejaram ser amadas, admiradas, mas só receberam desprezo, descaso, se tornaram pessoas muito sensíveis, por isso querem muita atenção. Ou então ela pode se tornar uma pessoa durona, autoritária, que camufla seus sentimentos, se esconde atrás de uma couraça, achando que o chorar ou o se emocionar são sentimentos negativos.

Muitas mágoas que nos ocorrem neste mundo, são difíceis de serem definidas. Elas fazem parte da vida que levamos neste mundo decaído. Muitas crianças são humilhadas, rejeitadas, depreciadas pelos seus próprios familiares. Quanto sentimento de ódio, raiva, medo são lançados numa mente infantil, e ali infeccionam tornando-se em gangrena, e um dia chegam a afetar toda a personalidade, quando já adultos sofrem por ter que conviver com esta situação, que parece ter passado, mas na realidade está lá ainda guardado no fundo do seu arquivo, comentários que geraram medo e timidez. Por não saber lidar com o perdão de Deus, as pessoas não conseguem perdoar a quem lhes causou algum mal. Por terem dificuldades de entender, compreender e receber a grandeza da Graça de Deus, têm dificuldades de praticar a graça, de amar as pessoas. Não sabem receber e, consequentemente, não sabem dar! Este tipo de pessoa vive amargurada, complexada, cheia de ódio, sentimentos de vingança, em relação àqueles que, na sua história de vida, lhe machucaram! Como não sabem vivenciar a Graça, não conseguem viver com seus sentimentos de amor, de perdão, de renúncia, de tolerância. 
É preciso que retiremos os sentimentos negativos do coração para sentirmo-nos livres e conseguirmos perdoar. "Antes sede bondosos uns para com os outros, compassivos, perdoandovos uns aos outros, como também Deus vos perdoou em Cristo." - Efésios 4:32. Não podemos receber o perdão de deus enquanto não perdoarmos nosso irmão de todo o nosso coração. Entre tudo o que se pode fazer, o melhor tratamento para cura da falta de perdão é a aceitação imediata do perdão de Deus, e a sua aplicação, perdoando a quem o ofendeu e se perdoando por culpas que carregou; A cura interior e a cura do corpo, muitas pessoas continuam convivendo com doenças, com dores e a causa e a falta do perdão, falta de liberar as suas mágoas.

Nós damos graças a Deus pela medicina. Lucas era médico, e foi inspirado pelo Espírito Santo para escrever sobre a história de Jesus. Deus deu ao homem inteligência e capacidade para criar os remédios e fazer uso deles. Os médicos tratam dos enfermos, mas é Jesus quem os cura! Jesus é o melhor Psicólogo! Ele nos fez, e sabe como somos, conhece nossos pensamentos, temperamento, problemas, traumas, melhor do que ninguém! Ele quer restaurar relacionamentos destruídos, como entre pais e filhos; reerguer casamentos desmoronados. Jesus deseja que sejamos capazes de amar os outros do mesmo modo como gostaríamos de ser amados. De perdoar da mesma forma como gostaríamos de ser perdoados. O desejo do coração do Senhor é que você seja aquela pessoa que Deus tinha em mente quando te criou, Jeremias 1:5 nos diz:- "Antes que eu te formasse no ventre te conheci, e antes que saísses da madre te santifiquei; às nações te dei por profeta.".

Para conseguir alcançar a cura interior você precisa antes de tudo admitir que precisa de cura; romper com o domínio de satanás sobre você e tomar posse do que é seu por direito isso significa vencer e superar toda rejeição, complexo, culpa, medo, timidez, orar pedindo a Deus que cure e apague em sua mente as lembranças sofredoras do passado.

Em Hebreus 10:17 lemos "E não me lembrarei mais de seus pecados e de suas iniquidades.". Se pudéssemos descobrir a origem de todos os traumas humanos, de todos os sofrimentos da alma, veríamos que, em última análise, eles são consequências do pecado de alguém, isso nos levaria a pensar que tudo pode ser mudado. Não existe comportamento desestruturado que o Senhor não possa mudar, pode ser o maior que for. Ele está aqui para lhe ajudar, é só você querer! Confesse hoje a Ele os seus temores! Ele sonda o seu coração e penetra nos compartimentos mais profundos do seu ser!. Ele renovará a sua mente, trazendo cura! Deus é o grande alquimista que transforma tudo o que há em nossa vida, em finíssimo ouro espiritual.

\section{DESENVOLVIMENTO}


Todo ser humano tem problemas. Alguns são pequenos, fáceis de serem resolvidos. Outros parecem que não têm tamanho, que nunca serão solucionados. Esses podem gerar consequências sérias e para a vida inteira. Seus efeitos podem atrapalhar um casamento, a profissão, a capacidade de aprendizado, relacionamento social e, principalmente, a vida espiritual. Então, livremo-nos deles.

Para tanto, observemos que há problemas do passado que não foram solucionados ou foram mal resolvidos, e hoje impedem de termos a vida abundante prometida por Jesus, Jo 10: 10. Com o tempo, o problema parece que vira uma necessidade pessoal, e aí, a pessoa perde o controle da situação e até da trajetória de sua vida. Chegamos a pensar em desistir do Cristianismo, ou da vida. Aparentemente, é como se não houvesse solução.

Situações negativas não devem ter domínio sobre o percurso da vida de um cristão: "lançando sobre ele toda vossa ansiedade, que ele tem cuidado de vós", 1Pe 5: 7. Entenda que problemas não são necessidades. Fale com Deus sobre essas questões. Permita que o Espírito Santo sare as feridas de sua alma, quebre o jugo que pesa sobre seu pescoço e abra o caminho para a vida abundante, Fp 4 19; S1 51: 3

Mais cedo ou mais tarde, todos passam pela experiência da lamentação. Os problemas geram lamentações, incertezas e palavras negativas, que são sementes ruins no dia a dia da vida cristã. Essa semeadura negativa produzirá consequências más, Pv 29: 25, porque as palavras têm poder de condicionar a mente do ser humano e levá-lo à destruição: “A boca do insensato é a sua própria destruição, e os seus lábios, um laço para a sua alma", Pv 18: 7. Por isso, troque as lamentações pela oração.

Viver reclamando, dar a impressão de que nada vai bem, aparentar que a vida nunca foi boa, que as coisas sempre deram erradas, etc, são alguns tipos de lamentações e isso gera desarmonia em relação às coisas boas. O Senhor disse para Moisés: "porque clamas a mim? Dize aos filhos de Israel que marchem", Êx 14: 15. O vocábulo hebraico tsa'aq, traduzido por 'clamas', é o mesmo que lamentação. Porque estavam reclamando da vida, esqueceram-se da promessa de libertação. Por isso, troque as reclamações pela oração.

Muitas vezes conosco isso também acontece. Porém, as lamentações acabam por afetar negativamente nosso mundo interior e nossa fé. A oração dá outra direção à vida do cristão. Em vez de continuar recuando, o Espírito Santo o fortalece, levando-o para frente, estimulando-o a continuar marchando. A oração toca o coração do Senhor, que sara nossas enfermidades, S1 103: $1-5$.

A filosofia popular afirma que "o medo é a certeza da desgraça que está para acontecer, não tenha medo, pois ele pode dominar você”. O medo gera pavor, receio, insegurança, tensão, 
angústia e ansiedade. Esse sentimento de grande inquietação, ante a noção de um perigo real ou imaginário, produz susto, pavor, temor e terror no coração humano.

Jó possuía qualidades que agradavam a Deus, mas trazia em sua alma o medo: “Aquilo que eu mais temia me aconteceu”, Jó 3: 25. Todos precisam vencer este fantasma que parte do mundo interior e afeta terrivelmente o exterior. Há crentes que trazem consigo este sentimento por causa de feridas na alma que não foram saradas, de fatos passados que deixaram forte impressão em seu coração. A fé bíblica em Deus sempre foi o melhor caminho para a destruição do medo e da cura de suas origens, no mundo interior.

Essa fé dá segurança espiritual e emocional na vida cristã: "O Senhor é a minha luz e a minha salvação; de quem terei medo? O Senhor é a fortaleza da minha vida; a quem temerei?", S1 27: 1. A palavra de Deus renova a mente e muda os conceitos negativos instalados na mente do cristão. O bálsamo do Espírito Santo sara as feridas da alma e produz cura interior.

\section{As feridas da Alma}

As feridas da alma são causadas por traumas psicológicos. Normalmente essas feridas na alma são consequência do modo como a pessoa foi educada pelos pais, estilo de vida, meio social e cultural.

Todos esses ambientes interferem diretamente em nossa persona, ou seja, em nosso eu interior. Qualquer lesão psicológica em uma dessas áreas pode desencadear feridas profundas na alma.

Segue alguns exemplos de doenças causada por feridas da alma:

Tabela 1

\begin{tabular}{|ll|}
\hline$\bullet$ & Transtorno Obsessivo Compulsivo \\
\hline$\bullet$ & Transtorno Bipolar \\
\hline$\bullet$ & Transtorno de ansiedade social \\
\hline$\bullet$ & Anorexia \\
\hline$\bullet$ & Depressão clínica \\
\hline$\bullet$ & Transtorno Dismórfico Corporal (TDC) \\
\hline$\bullet$ & Transtorno da Personalidade Borderline \\
\hline$\bullet$ & Estresse pós-traumático \\
\hline
\end{tabular}


- $\quad$ Depressão pós-parto

Fonte: Lagartense

O processo de cura da alma ferida começa com um relacionamento profundo com Deus por parte da pessoa que precisa de cura interior e por parte das pessoas que desejam ajuda-la.

Já concebemos que Deus é poderoso para curar qualquer doença, seja ela física ou na alma.

\section{Cura da Alma}

Quando se aproximaram de Jesus, viram que o homem de quem haviam saído os demônios estava assentado aos pés de Jesus, vestido e em perfeito juízo, e ficaram com medo. Os que o tinham visto contaram ao povo como o endemoninhado fora curado. (Lucas 8:35,36)

O exemplo do gadareno é um referencial poderoso de cura da alma, de cura e libertação.

Ele vivia tão oprimido que a convivência com ele já era impossível. As feridas da alma o deixaram agressivo. Ele causava pânico nas pessoas, de tal maneira que destruía correntes e vivia nos sepulcros.

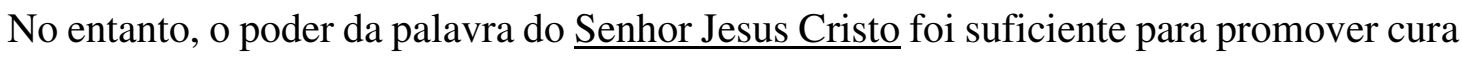
e libertação em sua alma ferida. A cura interior promovida pela poderosa palavra de Deus é conclusiva.

As pessoas que o viram após a cura e a libertação encontraram uma pessoa totalmente diferente.

O desejo de Deus é promover a cura da alma ferida pela manifestação do seu poder, de sua bondade, de sua misericórdia.

\section{Cura da Alma Através do Perdão}

Se perdoarem os pecados de alguém, estarão perdoados; se não os perdoarem, não estarão perdoados". (João 20:23)

Diversas pessoas estão precisando de cura interior por não conseguirem liberar perdão. É determinante que entendamos o conceito de perdão na Bíblia para ver quais os passos que devemos dar em busca da cura da alma através do perdão. 
Reter o perdão é prolongar o sofrimento. William Shakespeare já disse: "Guardar ressentimento é como tomar veneno e esperar que a outra pessoa morra."

Aproximou-se dele um leproso, suplicando-lhe de joelhos: "Se queres, podes limparme." Jesus compadeceu-se dele, estendeu a mão, tocou-o e lhe disse: "Eu quero, sê curado." E imediatamente desapareceu dele a lepra e foi purificado. Jesus o despediu imediatamente com esta severa admoestação: "Vê que não o digas a ninguém; mas vai, mostra-te ao sacerdote e apresenta, pela tua purificação, a oferenda prescrita por Moisés para lhe servir de testemunho." Este homem, porém, logo que se foi, começou a propagar e divulgar o acontecido, de modo que Jesus não podia entrar publicamente numa cidade. Conservava-se fora, nos lugares despovoados; e de toda parte vinham ter com ele.

O leproso está enfermo na sua relação com ele mesmo, na sua relação com as pessoas e também na sua relação com Deus.

Por que ele está doente na relação com ele mesmo? Imagine uma pessoa que tem lepra e como ela se sentiria com ela mesmo. Ela fica isolada. É uma pessoa que não se ama, que sente que não tem valor nenhum.

O leproso não se sente bem consigo mesmo, e ele acredita que Deus foi o pior para ele. Muitas de nós, podemos viver uma situação dessa, de sentirmos como um leproso, e até acharmos que Deus foi o pior para nós também.

Isso precisa ser curado, porque somos criaturas de Deus. Precisamos olhar no espelho e louvá-lo. Somos criados pelas mãos de Deus e é aquilo de mais formoso que Ele fez.

O leproso, segundo o livro de Levítico, não podia aproximar-se de ninguém porque ele poderia contaminá-lo. Muitos de nós, acreditamos igualmente assim, nos sentimos distantes de nossos irmãos. Supomos que não somos iguais aos outros.

Temos que pedir a Deus que sare nossa relação com as pessoas, porque temos que reconhecer uns ao outros como irmãos. É certo que tem gente que não merece esse reconhecimento por causa de uma traição, ou porque nos fizeram mal etc. E, se quisermos ser curados, precisamos aprender a amar e perdoar e a nos relacionar bem com essas pessoas.

\section{Relacionamento Com Deus}

Quanto ao nosso relacionamento com Deus, é preciso buscá-Lo de coração. Ao invés de se sentir longe de Deus por causa de sua enfermidade, você precisa buscar Deus e pedir que Ele cure sua enfermidade. Você até pode se afastar d'Ele, mas Ele nunca se afasta de você. Ele sempre vai querer te curar. 
É importante prestar atenção na nossa relação conosco mesmo, nossa relação com os outros e nossa relação com Deus. Nós temos que revisar essas relações.

$1^{\mathrm{a}}$ coisa - Não seremos felizes se não nos valorizarmos. Ninguém que não ame a si mesmo não tem como amar o outro. Amar não é mendigar, não é dependência emocional. Para ser curado diante de Deus, amemos o próximo como a nós mesmos. Por isso precisamos nos amar. Perguntemos a nós mesmos: como está nossa relação conosco mesmos? Se encontrarmos problemas, então é preciso investirmos em oração.

$2^{\mathrm{a}}$ coisa - Temos que perguntar como está nossa relação com os outros, porque se o nosso coração está cheio de rancor, mágoa, temos que pedir a Deus que sane nosso coração e nos dê um coração limpo.

$3^{\mathrm{a}}$ coisa - Perguntemo-nos como está nossa relação com Deus, porque não devemos nos sentir humilhados ou mesmo castigados por Deus. Ele nunca falha com você. Muitas vezes, uma pessoa pede aquilo que não convém e por isso Deus não dá. Ele nos dará as coisas de acordo com a Sua vontade.

Muitos de nós, não queremos ter problemas, mas se você não tem problemas é bem provável que você já esteja morto. Os problemas são sinais de que estamos vivos. Benditos problemas!

O leproso, levando seu problema, foi até Jesus. Quanto mais longe do Senhor, mais enfermo você ficará. Você precisa se aproximar do Senhor.

Depois de se aproximar do Senhor, o leproso se ajoelhou. Isso é uma atitude de reconhecimento, de adoração, de que Ele é mais importante que tudo. Ajoelhar-se é uma postura corporal para reconhece-Lo como Senhor. Enquanto não reconhecemos Ele como Senhor ficaremos doentes.

Nos aproximemos de Deus, ajoelhemo-nos, reconheçamo-lo como Senhor, e então, supliquemos a Deus, o que precisamos.

As feridas da alma não podem ser ignoradas. Elas causam diversos problemas emocionais e físicos. Ou seja, precisa ser tratado com urgência.

A cura da alma deve ser uma prioridade. Quando os sintomas surgirem coloque tudo em segundo lugar e busque diligentemente ao Senhor até que a sua cura venha.

Muitas pessoas no meio cristão, pessoas detentoras até mesmo de certo grau de estudo, de certo nível de conhecimento, têm dúvidas sobre o que a ciência e a Bíblia falam acerca da cura interior. E é sobre isso que vamos falar nesta mensagem.

\section{Entendendo Melhor Sobre Cura Interior}


A cura da alma do homem, assim conhecida tanto na sociedade como no meio evangélico. O tratamento começa quando passamos a buscar a causa da enfermidade e tentamos ajudar a pessoa a livrar-se dos traumas existenciais.

Nós, os evangélicos, que seguimos os ensinamentos de Cristo e procuram os pautar a nossa vida pelas Escrituras Sagradas, jamais desprezamos a ciência, pelos seguintes motivos: O próprio Jesus disse que os doentes precisam de médico (ver Mt 9.12) "Jesus crescia em sabedoria, e em estatura, e em graça para com Deus e os homens (Lc 2.52)".

As doenças da alma são manifestadas por meio de um esgotamento físico violento ou um esgotamento emocional profundo, o qual pode resultar em confusões emocionais e mentais, e surtos psicóticos. Se a pessoa não tomar a medicação adequada poderá contrair um desequilíbrio grave. Algumas recomendações quanto ao uso de antidepressivos:

-É preciso estar atento e ser cauteloso, porque a pessoa pode sair de um problema e entrar em outro, tornando-se um dependente químico;

-Não tome psicotrópicos sem necessidade, apenas para fugir de sofrimentos emocionais;

-A maioria das doenças que envolvem a alma do homem não se cura com remédios da alopatia ou da homeopatia, mas com ajuda espiritual;

$\mathrm{Na}$ linguagem bíblica, na maioria das vezes a palavra alma é traduzida como coração, e deve ser entendida como a sede da inteligência, dos sentimentos, da vontade e das emoções do homem, onde ficam localizadas as lembranças boas ou más. Estas ficam escondidas no coração e, com o passar do tempo, aparecem, provocando atitudes e comportamentos inexplicáveis, fazendo a alma adoecer: mensagens negativas — resultantes de um passado sofrido, más lembranças —, correria do dia a dia, violência nas ruas, luta pela sobrevivência de um modo geral, medo, vingança, ódio, orgulho, traumas de infância, comparações, humilhação, abuso, inconstância, mentir a, brutalidade, grosseria, vaidade, ansiedade, malícia, injustiça, perdas em geral, indecisões, relacionamentos fracassados, abandono psicológico, rejeição, entre outros.

Várias são as fontes que produzem doenças emocionais. Destacamos aqui algumas delas:

\section{$\underline{\text { A família }}$}

A família pode transferir-nos coisas boas e, assim, tornar-nos indivíduos de personalidade estruturada ou pode transmitir-nos coisas ruins, e ser responsável por tornar-nos indivíduos de personalidade desajustada. Nós somos, tanto no aspecto genético como no espiritual, reflexo dos nossos antepassados e dos parentes imediatos com quem convivemos. 
Muita gente pensa que será menosprezada e inferiorizada se não atingir determinado nível ou posição social, não conseguir conquistar certo nível de salário, não comprar o que todos estão comparando, não tiver um carro do ano, ou não se vestir de determinada maneira. Esses são comportamentos da cultura secular que podem produzir doenças da alma.

\section{A religião legalista}

No meio legalista, não se pode errar. A pessoa é obrigada a obedecer. Se não atingir um determinado padrão de perfeição, não poderá viver naquele meio. Conseqüentemente a pessoa passa a esforçar-se ansiosamente para alcançar tal padrão. A religião legalista, sem amor e graça, impõe regras que podem gerar doenças da alma.

\section{As escolhas erradas}

O ser humano é dotado de inteligência, vontade própria, sentimentos e livre-arbítrio, o que o torna responsável por suas próprias escolhas. Sendo assim, a pessoa pode assumir procedimentos errados, e atrair para si muitas doenças na área emocional, no que tange à sua alma, porque o remorso dói e as conseqüências são inevitáveis (Lm 3.39).

\section{$\underline{\mathrm{O} \text { abandono de Deus }}$}

Nos dias de hoje muita gente tem abandonado Deus e passado a viver a sua própria deidade. E, como eles se não importaram de ter conhecimento de Deus, assim Deus os entregou a um sentimento perverso, para fazerem coisas que não convém (Rm 1.28). O sentimento é uma faculdade da alma. E, cada vez que o homem despreza Deus, fica entregue a sentimentos perversos, sendo levado a padecer de muitas doenças emocionais.

\section{Não saber lidar com a graça de Deus}

Graça é favor imerecido. Ninguém merece nada. Deus simplesmente nos deu o Seu perdão e amor sem que nós os merecêssemos (Jo 3.16). Mas há pessoas que têm dificuldade de aceitar isso, pensam que não podem ter seus muitos pecados perdoados sem pagar algum preço ou passar por sofrimento. Por isso, contraem doenças emocionais graves. Essas pessoas não conseguem refletir sobre o fato de:

O Senhor ter-nos conhecido antes de sermos formados no ventre (Jr 1.5).

O Senhor ter-nos amado com amor eterno (Jr 313)

O Senhor ter tornado os nossos pecados brancos como a neve (Is1.18)

O Senhor ter lançado todos os nossos pecados nas profundezas do mar (Mq 7.19)

O Senhor jamais se lembrar de nossos pecados (Hb 10.17).

\section{$\underline{\text { A falta de perdão }}$}

Quem não perdoa vive amargurado, complexado, com o coração ferido, com sentimentos maus em relação àqueles que, na sua história de vida, machucaram-no. Como não 
sabe vivenciar a graça, não consegue viver com seus sentimentos de amor, perdão, renúncia e tolerância. É preciso que retiremos de nosso coração sentimentos negativos como ódio e mágoa e que consigamos perdoar nosso irmão.

\section{A espiritualidade excessiva}

Muitos cristãos querem espiritualizar tudo - é o que se chama de pseudo espiritualização. Essas pessoas têm se comportado como se não fossem seres humanos, nunca choram ou ficam tristes, tentam apresentar uma determinada postura que de fato é uma mentira. Elas dão glória a Deus até quando um filho morre, dizem que o cristão não fica triste, que tem de ser vitorioso em tudo. Porém, pessoas que se comportam assim podem tornar- -se doentes emocionalmente ou ficar loucas.

\section{$\underline{\text { A opressão }}$}

A opressão é o ato de humilhar, tiranizar, sobrecarregar com peso. Ela faz adoecer a alma e apresenta-se como demoníaca ou humana. A Palavra de Deus nos dá algumas referências sobre esse ato:

\footnotetext{
O Senhor não permitiu que o Seu povo fosse oprimido pelos inimigos (SI 105.14)

O salmista rogou ao Senhor que o livrasse da opressão do homem (S1 119.134)

O Senhor ordenou que os israelitas não oprimissem ao próximo ( Lv 25.17)

O Senhor curou a todos os oprimidos pelo diabo (At 10.38)

A opressão faz adoecer até o sábio (Ec 7.7)
}

\section{$\underline{\text { A depressão }}$}

Muitas são as causas que levam uma pessoa à depressão. Entre elas estão medo, vingança, ódio, orgulho, comparações, abuso, inconstância, complexos, mentira, grosseria, brutalidade, violência, selvageria, vaidade, ansiedade, angústia e malícia. Tudo isso, se não for tratado, faz a alma adoecer.

Alguns dizem que depressão é coisa do diabo. Na verdade, é algo de cunho emocional, é uma doença da alma. As ciências tentam explicá-la e encontram várias hipóteses, algumas dignas de credibilidade e consideração. Os médicos sabem de muitas origens, mas não de todas. E é fato que, quando a angústia chega, o vazio a cerca, e só Deus pode completar esse vazio do ser humano.

Quando falamos sobre cura interior, falamos sobre cura da ALMA..

Quando nos convertemos o nosso espírito é vivificado pelo Espírito Santo e é curado da culpa do pecado ( este é o maior milagre de Deus ). Está livre para ter comunhão com Deus, mas na nossa alma ficaram feridas, lembranças, traumas, do tempo que vivíamos na vida de pecado.. 
Nós não somos o que gostaríamos de ser. O Espírito Santo é o

Espírito da verdade, ele nos revela quem nós realmente somos.

Tudo que Deus revelar durante este tempo, falhas de caráter, pessoas que você magoou, pecados encobertos, etc. anote . Seja sincero com você mesmo, conheça a verdade e a verdade te libertará. Jo 8:32

Lamentavelmente, muitas pessoas estão doentes em seu interior! E como existem pessoas doentes deixando outras doentes também! Porque a doença da alma, quando não é tratada, contamina outros ao redor... são muito críticas, pessimistas, não está bom, tendentes a sempre ver, pensar e sentir o pior, são pessoas sempre doentes. Pedem conselhos, mas nunca colocam em prática? ... são pessoas desconfiadas, inseguras... Que fisicamente estão bem, desfrutam de ótima saúde, mas estão doentes por dentro.

Existe Cura Para Alma Doente?

"É Ele que perdoa todos os seus pecados e cura todas as suas doenças." S1 103.3

"Só ele cura os de coração quebrantado e cuida das suas feridas." S1 147.3

I. Existem dois grupos de doentes da alma:

1. Os que admitem;

2. Os que ignoram;

II. Entre os que admitem, também existem dois grupos:

1. Os que admitem e nada fazem para mudar a situação,

2. Os que admitem e buscam ajuda,

III. Os que buscam ajuda, geralmente o fazem...

Buscando ajuda na Psiquiatria

A palavra Psiquiatria deriva do Grego e quer dizer "arte de curar a alma" Esta não é uma especialidade humana e sim divina. A Psiquiatria é o ramo da medicina que lida com a prevenção, atendimento, diagnóstico, tratamento e reabilitação das doenças mentais, sejam eles de cunho orgânico ou funcional, tais como depressão, doença bipolar, esquizofrenia e transtornos de ansiedade. A meta principal é o alívio do sofrimento psíquico e o bem-estar psíquico. A própria psiquiatria admite: "Muitas doenças psiquiátricas ainda não tem cura." A efetividade do tratamento também varia em cada paciente. Existe uma grande diferença entre doença EMOCIONAL e ESPIRITUAL.A psiquiatria não tem poder para curar a alma humana de problemas gerados pela ausência de Deus!

Buscando ajuda Espiritualista:

Vivemos num país religioso desde suas raízes e do seu descobrimento. Este "mix" de religiões tem gerado pessoas cada vez mais DOENTES! Passe magnético, água fluidificada, 
aromaterapia, terapia com florais, terapia de vidas passadas, banho de descarrego (Banho de sal grosso), fez yoga, cromoterapia, e nada adianta... A espiritualidade sem Jesus não tem poder para curar a alma humana de problemas gerados pela ausência de Deus!

Buscando ajuda Religiosa:

Não falta religião no mundo! Hinduísmos, xintoísmo, budismo, judaísmo, islamismo, cristianismo, catolicismo, até ateísmo. São tantos "ismos" Religião não salva, não cura, não restaura a vida das pessoas! Mas pode deixar doente e até matar. A religião, em especial neste início de século tem sido a $4^{\mathrm{a}}$ maior causa de morte do mundo (Sendo superada apenas pelas doenças, miséria e catástrofes naturais).

Os três caminhos sempre num primeiro momento parecem ser bons, mas os 3 podem NÃO RESOLVER, OU PIOR, GERAR AINDA MAIS PROBLEMAS. Então o que fazer? Buscar diretamente a Deus, através de Jesus. Decisão pessoal e genuíno arrependimento!

Passos para tratar a alma ferida:

* ORAR ENTREGANDO TUDO PARA DEUS, abrir o coração para Deus: v. 8 Salmo 37: 5 - Entrega o teu caminho ao Senhor; confia nele, e ele tudo fará. A ORAÇÃO FEITA COM FÉ, NUNCA FICARÁ SEM RESPOSTA!

* LOUVAR A DEUS POR TODAS AS SITUAÇÕES: Vs. 4-5.“Quando me lembro destas coisas choro angustiado. Pois eu costumava ir com a multidão, conduzindo a procissão à casa de Deus, com cantos de alegria e de ação de graças entre a multidão que festejava...Ponha a sua esperança em Deus! Pois ainda o louvarei; ele é o meu Salvador e o meu Deus".

Habacuque 3: 17 a 19 - Ainda que a figueira não floresça, nem haja fruto nas vides; ainda que falhe o produto da oliveira, e os campos não produzam mantimento; ainda que o rebanho seja exterminado da malhada e nos currais não haja gado. Todavia eu me alegrarei no Senhor, exultarei no Deus da minha salvação. O Senhor Deus é minha força, ele fará os meus pés como os da corça, e me fará andar sobre os meus lugares altos.

O ditado popular diz: "quem canta seus males espanta", mas a verdade, porém,

"É que quem louva, seu trauma estanca e os males espanta."

* ESPERAR EM DEUS: v. 5“Ponha a sua esperança em Deus”. Ele diz à sua alma

"Espera em Deus, pois ainda o louvarei pela salvação que há na sua presença". Salmo 71:14 -Mas eu esperarei continuamente, e te louvarei cada vez mais. "Não há salvação em nenhum outro, pois, debaixo do céu não há nenhum outro nome dado aos homens pelo qual devamos ser salvos”. At. 4:12. Mas somente em Jesus há salvação. Se entregue a Jesus, deixe que Ele cure a sua alma, sare as suas feridas, perdoe seus pecados e lhe dê a salvação! 
* CONFIAR DE TODO SEU CORAÇÃO: v. 11 "Pois ainda o louvarei; ele é o meu Salvador e o meu Deus." É entregar tudo. Decisão pessoal e imediata!!! A ansiedade gera uma série de doenças da alma. A entrega é a melhor decisão.

Devemos descansar no Senhor sabendo que Ele nos sonda e nos conhece.

SALMO.139:1Senhor, tu me sondas, e me conheces.

$2 \mathrm{Tu}$ conheces o meu sentar e o meu levantar; de longe entendes o meu pensamento.

3 Esquadrinhas o meu andar, e o meu deitar, e conheces todos os meus caminhos.

4 Sem que haja uma palavra na minha língua, eis que, ó Senhor, tudo conheces.

5 Tu me cercaste em volta, e puseste sobre mim a tua mão.

6 Tal conhecimento é maravilhoso demais para mim; elevado é, não o posso atingir.

7 Para onde me irei do teu Espírito, ou para onde fugirei da tua presença?

8 Se subir ao céu, tu aí estás; se fizer no Seol a minha cama, eis que tu ali estás também.

9 Se tomar as asas da alva, se habitar nas extremidades do mar,

10 ainda ali a tua mão me guiará e a tua destra me susterá.

Deus sabe todas as coisas

Existe muita especulação sobre este assunto e ele tem sido aplicado de muitas maneiras erradas.

Quando falamos sobre cura interior, falamos sobre cura da ALMA.

Quando nos convertemos o nosso espírito é vivificado pelo Espírito Santo e é curado da culpa do pecado este é o maior milagre de Deus.

Está livre para ter comunhão com Deus, mas na nossa alma ficaram feridas, lembranças, traumas, do tempo que vivíamos na vida de pecado.

Nós não somos o que gostaríamos de ser.

Descobrimos várias verdades em nossa vida que precisam ser encaradas e enfrentadas. O Espírito Santo é o Espírito da verdade, ele nos revela quem nós realmente somos.

Tudo que Deus revelar durante este tempo, falhas de caráter, pessoas que você magoou, pecados encobertos, seja sincero com você mesmo, conheça a verdade e a verdade o libertará. Jo $8: 32$

A cura está na Palavra de Deus.

Devemos ter fé e não subestimar o poder de Deus. Ele pode mudar tudo. Ele pode curar todas as pessoas.

Quem precisa de cura interior

Você se aceita assim como é, aparência, limitações, cor, sexo, casado, solteiro, situação econômica ,ou usa de vários artifícios para mudar? 
- $\quad$ Se e não gosto de mim dificilmente vou gostar dos outros.

- $\quad$ É impossível agradar uma pessoa que não está contente consigo mesma.

- $\quad$ Se você fosse desenhar a si mesmo, como se desenharia ?

- $\quad$ Aceita a si mesmo sem revolta ?

- $\quad$ Você se acha, ou acha que as pessoas o consideram uma pessoa amarga ?

- $\quad$ Não tolera a si mesmo.

- $\quad$ Está sempre de mau humor.

- $\quad$ É difícil para você se aproximar de outras pessoas, estabelecer diálogos, romper ambientes

- $\quad$ Timidez, esconde o verdadeiro "eu" .

- $\quad$ Complexo de inferioridade

- Você está sempre na defensiva ou sempre no ataque ? Desconfia de todos ?

- $\quad$ Por desconfiar fica na defensiva

- $\quad$ Não se abre para relacionamentos

- Quando você vai a uma reunião cumprimenta os outros ? Ou fica esperando que eles venham?

- $\quad$ Fica observando quem não veio cumprimentar.

- $\quad$ Fica chateado com isso.

- Você acha que é demasiadamente tímido, áspero ou duro com os outros?

- $\quad$ Se passa por humilde.

- $\quad$ Sempre dá respostas grosseiras.

- Você usa com freqüência ironias, zombarias, sendo ferino em suas observações? (Sarcástico)

- É irreverente

- Você usa ares de suficiência, prepotência com os outros ? (Autossuficiência)

- Não existe complexo de superioridade. Isso é apenas uma capa para esconder um sentimento de inferioridade e insegurança

- $\quad$ Você tem dificuldade de olhar os olhos das pessoas para conversar ?

- $\quad$ Medo de se expor

- Você é o que é na sua intimidade ( em casa )

- Você acha que as tarefas que os outros fazem são sempre mais importantes que as suas?

- $\quad$ Nunca está contente com o que faz.

- $\quad$ Se acha sem valor. 
O Homem

I Ts $5: 23$

O ser humano é tripartido. Todo homem é espírito alma e corpo. O corpo é diferente da alma e a alma é diferente do espírito. ( diferente do Espírito Santo )

O homem é um espírito que tem uma alma e habita num corpo.

\section{ESPIRITO Mente}

ALMA Vontade

CORPO Emoções

A pior enfermidade é a enfermidade do espírito.

É o pecado do homem. Ao nos convertermos ficamos livres da culpa do pecado, mas não das conseqüências da vida de pecado e das marcas que o pecado criou em nossa alma, por exemplo:

-Na mente: lembranças desagradáveis, fortalezas, insegurança, medo, amargura, sentimento de culpa.

-Na Vontade: inconstância, falta de iniciativa, indecisão, procrastinação (sempre deixar para depois), obstinação, medo de fracassar, derrotismo, vontade frouxa, falta de "acabativa", etc.

O homem era um ser governado pelo espírito

Após a queda o espírito do homem morreu para Deus e o homem perdeu a comunhão com Ele.

O homem passou a ser governado pela sua alma.

O corpo sofre as conseqüências das enfermidades da alma. Ele é afetado por elas e também fica enfermo. (conseqüência do desequilíbrio)

\section{A Cura da Alma Pela Ciência}

Citamos neste tópico algumas personalidades da psicanálise que abriram caminho para o tratamento e a cura das doenças da alma.

\section{$\underline{\text { Sigmund Freud }}$}

Este judeu alemão nascido na antiga cidade de Freiberg (antiga região da Morávia, no extinto Império Austro-húngaro e hoje República Tcheca) foi o fundador da psicanálise e do método de investigação psicológica empregado no tratamento das neuroses por meio da procura das tendências e influências reprimidas no inconsciente do individuo, e do seu retorno ao consciente pela análise. 


\title{
Erich Fromm
}

Alemão de família judia que deu interpretação própria às finalidades da terapêutica, impondo notações sociológicas ao estudo do ajustamento do indivíduo ao meio social e cultural.

\section{Jacques Lacan}

Médico francês especializado em psiquiatria, chefe de uma importante escola de psicanálise no país e que exerceu grande influência sobre a psicanálise nacional como intérprete das obras de Sigmund Freud.

A Palavra de Deus é mais importante do que qualquer teoria da psicanálise. Vejamos por quê:

\author{
O Espírito de vida nos livrou da lei do pecado e da morte (ver Rm 8.2) \\ O coração alegre é como o bom remédio (ver Pv 17.22) \\ O coração com saúde é a vida da carne (Pv 14.30a) \\ O coração do salmista ficou perturbado por inveja dos ímpios e, só depois de entrar \\ no templo, entendeu o fim deles (ver Si 73.1 7-1 9)
}

A maioria das doenças da alma não deveria ser tratada com remédio, mas sim com a Palavra de Deus. Como Ele nos criou, conhece-nos e entende-nos mais do que qualquer psicanalista ou psicólogo. A Palavra de Deus penetra na divisão da alma e do espírito (Hb 4.12) e abre os nossos olhos quanto aos pecados que podem causar doenças espirituais (1 Co 6.9-11).

Apresentaremos agora algumas receitas para a cura interior:

\section{Análise introspectiva}

Se você está vivendo uma situação como a do salmista, cujas lágrimas serviam-lhe de mantimento ( $\mathrm{Si}$ 42.3), saiba que o choro constante é sintoma de depressão. Esta provocava no salmista doenças psicossomáticas, atingindo os seus ossos ( $\mathrm{Si}$ 42.10). Mas ele obteve uma importante receita no versículo 11 .

\section{$\underline{\text { Oração }}$}

Essa é uma terapia. Quando você dobra os seus joelhos, pode contar tudo para Deus, falar tudo o que está machucando, sem medo ou vergonha.

Façamos um paralelo entre a terapia humana e a divina. $\mathrm{O}$ que acontece com um paciente que está frente a frente com um terapeuta?

Na terapia humana, o segredo é falar o máximo que puder e colocar tudo o que sente para fora. Acontece o processo de transferência, o paciente joga os seus problemas sobre o terapeuta, que, para não ficar doente, faz uma contratransferência.

$\mathrm{Na}$ terapia divina, as nossas petições devem em tudo ser conhecidas diante de Deus pela oração e súplica, com ação de graças (Fp 4.6). O processo é fazer o que a Palavra de Deus nos manda: lançando sobre ele toda a vossa ansiedade, porque ele tem cuidado de vós (1 Pe 5.7). 


\section{$\underline{\text { Relacionamentos pessoais }}$}

O ser humano é um ser social. Você nunca será uma pessoa inteira, completa, se não tiver e não construir relacionamentos. Quem vive isolado é um forte candidato a doenças da alma. Lembre-se de que nós fazemos parte do Corpo de Cristo (ver 1 Co 12.12,25-27).

\section{$\underline{\text { Relacionamento com Deus }}$}

Na psicologia, quando se faz o levantamento do histórico da vida de uma pessoa, faz-se o procedimento que, na medicina, chama-se anamnésia. Realizando o mesmo, busquemos na Bíblia a história de três homens que superaram os momentos de terríveis sofrimentos. São eles:

*José

Ainda adolescente, teve um sonho. Movidos pela inveja, seus irmãos o venderam como escravo a uns mercadores que iam para o Egito (Gn 37.28). José passou por situações de perda e injustiça, tendo tudo para ser depressivo. Porém, em nenhum momento esses sentimentos invadiram a alma dele. Em Gênesis 41.38 e 41.51,52 lemos como esse servo foi exaltado pelo Senhor a ponto de tornar-se governador do Egito.

*Jó

Jó, o homem mais rico do Oriente, perdeu, em um só dia, três mil camelos, sete mil ovelhas, quinhentas juntas de boi, quinhentas jumentas e os dez filhos. Qualquer pessoa em seu lugar teria enlouquecido. Mas ele, que costumava oferecer todos os dias sacrifícios por ele e pela sua família (Já 1.5), em meio a esse sofrimento, manteve-se firme. Ele sabia que o seu Redentor vive (Já 19.25-27) e, por isso, Deus virou o seu cativeiro, concedendo-lhe o dobro de tudo quanto tinha (Jó 42.10).

*Paulo

Paulo também teve muitos motivos para ser um homem cheios de complexos na vida. Ele consentiu na morte de Estevão e outros irmãos, e perseguiu os cristãos. Mas, quando conheceu o Senhor, passou a dizer que sabia em quem tinha crido (2 Tm 1.12). E, no final de sua carreira, disse: "Combati o bom combate, acabei a carreira, guardei a fé (2 Tm 4.7)."

Os Problemas emocionais também são curados pelo poder do pensamento. É por meio dele que articulamos as idéias que vão dirigir as nossas ações. Veja o que Paulo escreveu sobre o assunto em Filipenses 4.8. E devemos estar inconformados com o mundo (Rm 12.2) e despojar-nos do velho homem (Ef4.22,23).

Jesus recomendou que não nos inquietemos com o dia de amanhã (Mt 6.34). Mesmo assim, existem pessoas que não dormem hoje preocupadas com o que vai acontecer no próximo mês, e mergulham com tal intensidade nesse tipo de preocupação que ficam com o sistema nervoso abalado. Porém, a Bíblia nos convida a nos alegrar no dia que o Senhor fez (Si 118.24). 


\section{Ter boa expectativa da vida}

Existem pessoas que só dizem coisas ruins e negativas, não conseguem ver o lado positivo da vida, e assim atraem para si o que há de pior, provocando doenças na alma. Mas Jesus disse que a candeia do corpo são os olhos (Mt 6.22,23). Por isso, viva com otimismo e sorria, pois a maneira como encaramos a vida dirá se temos trevas ou luz em nosso interior.

\section{CONSIDERAÇÕES FINAIS}

Cura Interior é o processo pelo qual, por meio da oração, numa dinâmica espiritual, somos libertos de sentimentos de ressentimento, rejeição, tristeza, culpa, medo, ódio, complexo de inferioridade...

Em Rm 12.2 lemos: "Não vivam como vivem as pessoas deste mundo, mas deixem que Deus os transforme por meio de uma completa mudança da mente de vocês. Assim vocês conhecerão a vontade de Deus, isto é, aquilo que é bom, perfeito e agradável a ele".

Jesus disse isto: "Deixo com vocês a paz. É a minha paz que eu lhes dou; não lhes dou a paz como o mundo a dá. Não fiquem aflitos, nem tenham medo" (Jo 14.27).

Mas há inúmeras pessoas hoje que não possuem essa paz interior... muitas são crentes, mas acham-se emocionalmente enfermas.

Algumas não entendem como é possível, se já são cristãos!

Aquele verso da Bíblia de 2Co 5.17 precisa ser bem compreendido... ele diz: "Quem está unido com Cristo é uma nova pessoa; acabou-se o que era velho, e já chegou o que é novo".

Nós somos constituídos de três partes: temos corpo, alma e espírito.

O que se fez novo em nós? ...o espírito... o espírito é que nasceu de novo! Mas nosso corpo e nossa alma, não nasceram de novo. Tudo neles ainda é velho!

Então, o que fazer ao corpo e à alma? ...a Bíblia diz, quanto ao corpo, que ele deve ser dominado, controlado: 1Co 9.27 diz: "Eu trato o meu corpo duramente e o obrigo a ser completamente controlado...”. Isso é exercer domínio próprio.

E quanto à alma? ...a Bíblia diz que ela precisa ser renovada. Rm 12.2: "Não vivam como vivem as pessoas deste mundo, mas deixem que Deus os transforme por meio de uma completa mudança da mente de vocês".

Portanto, todos os cristãos ainda têm pela frente dois processos importantes: precisam dominar o corpo e renovar a mente, a alma (a alma é composta de: sentimento, vontade, pensamento, consciência). 
Mesmo que alguém ache que não tem feridas e que por isso, não necessita de cura interior, ao se deparar com a ordem "...deixem que Deus os transforme por meio de uma completa mudança da mente de vocês", é forçado a entender, através da Palavra de Deus, que precisa de renovação.

Se ao lembrar de um fato (rejeição, abandono...) você sente dor, é porque a ferida ainda não cicatrizou. Ocorre então uma dor na alma - essa dor se apresenta de diversas formas: Nojo, raiva, angústia, medo, vergonha...

Uma pessoa disse: "Sinto muito inveja do meu irmão, que era o filho que minha mãe preferia...”.

Outra pessoa disse: “...sinto nojo todas as vezes ao lembrar que fui violentada”.

Há casos da alma estar ferida, mas que a pessoa não sente, conscientemente, qualquer dor. Mas a alma está ferida, então, ocorre da pessoa ter algum comportamento pouco sadio.

Por exemplo: a pessoa não sente raiva do irmão que era preferido da mãe, mas não tem assunto com ele... há uma barreira...

A pessoa não sente nojo ou raiva ao lembrar de como foi molestada sexualmente, mas não consegue manter um relacionamento afetivo firme.

Outros sintomas de feridas de alma são os seguintes:

Viver ameaçando... jamais admitir os próprios erros... sentir prazer na desgraça do outro... não ter aspirações, sonhos... ser ciumento... ser triste... ser risonho demais... gastar o que não tem... ter dificuldade para dizer não... ter timidez paralisante... masturbar-se compulsivamente...

Há situações que nos ferem emocionalmente;

A família é a nossa base, se foi desestruturada, você também pode ter sido desestruturado.

Talvez aconteceram muitas coisas no período em que você ainda estava no ventre de sua mãe, e durante a sua infância e adolescência, que lhe afetaram diretamente.

Jesus tem poder para curar os seus traumas, as suas feridas interiores e até as suas doenças. Jesus veio para isto! E hoje, Ele vai tratar você, tirando o que foi plantado e não presta.

A Bíblia mostra homens e mulheres que tinham feridas na alma e que precisaram ser curados por Deus:

Moisés tinha dificuldade na fala (língua presa, talvez)...quem sabe, por conta disso, se achava incapaz de falar ao Faraó do Egito?

Elias foi um poderoso profeta, mas sentiu-se inferiorizado e incapaz de enfrentar Jezabel... entrou em depressão, queria morrer... 
Mirian, irmã de Moisés, sentia-se inferior a Moisés e quis se exaltar, afirmando ser usada por Deus... ficou leprosa...

Há muitas portas que, sendo abertas, geram feridas emocionais:

É o caso da rejeição - sentimento de que não somos amados, aceitos ou bem-vindos. A pessoa rejeitada sempre interpreta mal as atitudes das outras pessoas, tendo a sensação de desprezo... A rejeição vem através de várias situações:

O nome próprio, registrado em Cartório, pelos pais;

Morte do pai, da mãe ou de ambos... inconscientemente a pessoa assimilou como rejeição;

Gravidez indesejada - talvez a pessoa sido resultado de relação da mãe com um namorado que a abandonou;

Divórcio dos pais;

Preferência dos pais - o pai dá preferência a um filho mais inteligente, bonito, descontraído, e esquece o outro filho;

Rejeição no casamento: o marido rejeita a esposa porque está gorda, fala coisas desagradáveis para ela, humilha;

Abandono da mãe; a mãe que deixa filho com a avó ou o pai, para ir trabalhar em outra cidade ou morar com outro homem, ou vice-versa;

Palavras que geram maldições: mãe ou pai que lançou palavras, chamando o filho de burro, prostituta, gay, que nunca devia ter nascido, não presta para nada, não vale nada, não vai dar em nada;

Há muitas palavras que amaldiçoam: ah! você nunca vai prestar para nada... você é pobre, conforme-se com isso... você vai virar uma prostituta se continuar assim... homem que é homem não chora... ser homem mesmo precisa ter relações sexuais antes de casar...

A rejeição também vem de apelidos dados em virtude de alguma deformação: Narigudo, Orelhudo, Baleia, Palito...

Há rejeição que se instala devido à carência afetiva: o pai ou mãe que nunca disse que amava o filho, que nunca lhe fez carinho ou deu abraço...

Tem também aquele sentimento de rejeição que é auto-imposto, isto é, a própria pessoa se impõe: deficiência física... magreza excessiva... obesidade... seios muito grandes... cravos e espinhas em excesso... doenças constantes...

Também, algumas pessoas carregam feridas de alma em virtude da culpa.

Culpa por ter abortado ou pago o aborto para alguém... culpa pela morte de alguém... culpa por espancar filhos ou irmãos... culpa por ter roubado, enganado... culpa por ter sido abusado sexualmente de alguém... culpa por não ser mais virgem...

Por tudo isso, é que você hoje, talvez seja: inseguro, medroso, birrento, rancoroso, magoado, tímido, assustado, solitário...

Porém, considere o poder de Jesus, Ele é o maior dos médicos - médicos e enfermeiros tratam dos doentes, mas é Jesus quem os cura!

E em assuntos de alma, Jesus é especialista... Ele deseja sarar nossas tristezas e mágoas... quer que sejamos sadios!

Talvez você já viu um cartãozinho, onde aparece escrito assim: Médico Cirurgião: Dr Jesus Cristo (Médico dos médicos)... Consultório: em toda parte... Graduação: Filho de Deus... Sua Especialidade: o Impossível... 
Creia no seu coração: Jesus Cristo é o mesmo ontem e hoje e o será para sempre... o tempo e o espaço não significam nada para Ele - Jesus pode voltar ao nosso passado e tocar aqueles pontos em que fomos feridos.

Cura interior é isso: é deixar que Jesus faça Sua luz brilhar em todos os recantos escuros da alma, onde Satanás entulhou as mágoas e lembranças dolorosas.

Muitas vezes pensamos: “Ah! não quero ficar lembrando destas coisas ruins!” ...mas isto é como acumular objetos dentro de um armário. Você fecha a porta e não vê, mas as coisas estão lá e um dia rolarão para fora.

Pode ser que você esteja vivendo angústias e tenha marcas profundas na alma, ou esteja tentando superar vários problemas, melhorar sua qualidade de vida, mas, de repente, você se veja caindo novamente naquele túnel de tristeza. Procure, então, orar com sinceridade diante de Deus. Se você derramar o seu coração na presença do Senhor, Ele curará as suas feridas. Se enfrentamos problemas assim, busquemos através da Palavra de Deus, da oração, com jejuns, o bálsamo do Espírito Santo e a cura interior. Somos alvos do amor Deus. Ele nos ama muito e não quer que vivamos cabisbaixos e sem nenhuma perspectiva de vitória. Olhemos para frente, para o alto. Confessemos nossos pecados e os abandonemos. Não fiquemos comentando-os com terceiros, relembrando suas derrotas e fracassos. Deixemos nossos problemas nas mãos de Deus. Façamos um concerto com Ele. E façamos propósitos sérios para nossa vida moral e espiritual. Somos seres especiais. Vençamos a inquietação, a ansiedade, cuidemos bem de nós mesmos. Busquemos a cura interior.

\section{REFERÊNCIAS BIBLIOGRÁFICAS}

ALVES, Paulo César \& M. C. Rabello. "Repensando os estudos sobre representações e práticas em saúde/doença” In Alves, Paulo César \& M. C. Rabello (Orgs.): Antropologia da Saúde: traçando identidades e explorando fronteiras. Rio de Janeiro: Fiocruz/Relume Dumará, 1998. BÍBLIA SAGRADA

CSORDAS, Thomas. Corpo/Significado/Cura. Ed. Porto Alegre, UFRGS, 2008.

DOUGLAS, Mary “Magia e Milagre”. In Pureza e Perigo. São Paulo: Ed Perspectiva, 1970.

GOMES, Wilson. Nem anjos nem demônios. In Antoziazzi, Alberto et al. Nem anjos Nem Demônios. Interpretações sociológicas do pentecostalismo. Petrópolis: Vozes, 1994.

LEWIS, Ioan M. “Transe e possessão". In Êxtase Religioso: Um estudo antropológico da possessão por espírito e do xamanismo. São Paulo: Perspectiva, 1977. 
LÉVI-STRAUSS, Claude. A Eficácia Simbólica. In Antropologia Estrutural. Tempo Brasileiro, Rio de Janeiro, 1967a.

MALAFAIA, Silas. Cura Interior à Luz da Bíblia. Central Gospel, Rio de Janeiro, 2009.

MAUÉS, Raymundo Heraldo. Ciências Sociais e Religião, Porto Alegre, 2000.

MAUÉS, R. Heraldo; K. B. Santos \& M. C. Santos. "Em busca da cura: ministros e "doentes" na Renovação Carismática Católica”. Trabalho apresentado na XXII Reunião Brasileira de Antropologia, Brasília/DF, 15-19/07/2000.

MINAYO, Maria Cecília de Souza. Representações da Cura no Catolicismo popular. In Paulo César Alves \& Maria Cecília de Souza Minayo (Orgs.): Saúde e Doença: Um olhar antropológico. Rio de Janeiro: FIOCRUZ, 1994.

MONTEIRO, Duglas Teixeira. Igrejas, Seitas e Agências: Aspectos de um ecumenismo popular. In A cultura do povo. $4^{\circ}$ Ed. São Paulo: Cortez: Instituto de Estudos Especiais, 1988. MONTERO, Paula. Magia e Pensamento Mágico. Editora Ática. Série Princípios, 1986

NICOLAU, Roseane Freitas. A aflição e a cura. In O Caminho da Fé: um estudo da conversão religiosa ao pentecostalismo e suas implicações na vida do sujeito. Dissertação de Mestrado em Antropologia. Belém: UFPA, 1997.

PIERUCCI, Antônio Flávio \& Prandi, Reginaldo A Realidade Social das Religiões no Brasil Ed. Hucitec, São Paulo, 1996.

RABELLO, Mirian Cristina M. Religião, ritual e cura. In Paulo César Alves \& Maria Cecília Minayo (Orgs.): Saúde e Doença: Um olhar antropológico. Rio de Janeiro: FIOCRUZ, 1994. ROTHE, Rosa Marga. A chegado dos missionários "quadrangulares" na metrópole da Amazônia. In Pentecostais, Protestantes? Um estudo na Igreja do Evangelho quadrangular em Belém. Dissertação de Mestrado em Antropologia. Belém: UFPA, 1998. (mimeo) VOLCAN, Marcos Dione U. Renovação Carismática Católica, PUCRGS, 2003. 